\title{
Characterization of Isolated Antibacterial Compounds from Euphorbia Cotinifolia Methanol Extract
}

\author{
Jayalakshmi Basavegowda ${ }^{\text {1*(D) }}$, Raveesha Koteshwar AnandRoa ${ }^{2}$ (D) , Amruthesh Kestur Nagaraj ${ }^{3}$ (D) \\ 1 Post-Graduate Department of Botany, Maharani's Science College for Women, Mysore-570 006, Karnataka, India \\ 2 Department of Water \& Health, Faculty of Life Sciences, JSS Academy of Higher Education and Research, Sri \\ Shivarathreeshwara Nagara, Mysuru, Karnataka, India \\ 3 Applied Plant Pathology Laboratory, Department of Studies in Botany, University of Mysore, Manasagangotri, Mysore- \\ 570 006, Karnataka, India \\ * Correspondence: jayalakshmib74@gmail.com;
}

Scopus Author ID 6505977311

Received: 30.06.2020; Revised: 6.09.2020; Accepted: 10.09.2020; Published: 13.09.2020

\begin{abstract}
Infectious diseases are emerging at an alarming rate, which is posing a great threat to the population because of the continuous battle with pathogens. Green plants are rich in bioactive molecules providing valuable sources of antimicrobial compounds. Antibacterial activity of various solvent extracts of E.cotinifolia leaves was screened against some human pathogenic bacteria like Bacillus subtilis, Bacillus cereus, Staphylococcus aureus, Klebsiella pneumonia, Salmonella typhi, Escherichia coli, and Enterobacter aerogenes by agar cup diffusion and minimum inhibitory concentrations (MIC) determined by micro broth dilution Methanol extract of Euphorbia cotinifolia was separated by silica gel column, leading to the isolation of new compounds and structure was elucidated by spectroscopic techniques. The solvent extracts and newly isolated compounds were tested for their antibacterial activity. Methanol and ethyl acetate recorded significant activity against Enterobacter aerogenes and Bacillus subtilis, which showed a maximum inhibition zone of $17.25 \mathrm{~mm}$. MIC ranged from $0.3-1.25 \mathrm{mg} / \mathrm{mL}$ for methanol and ethyl acetate extracts. The inhibition zone measured against test bacteria was $15.25-19.50 \mathrm{~mm}, 13.50-19.25 \mathrm{~mm}, 12-18.50 \mathrm{~mm}, 15-20 \mathrm{~mm}$, and 13- $19 \mathrm{~mm}$ in ECMF1, ECMF2, ECMF3, compound 1, respectively, and MIC of the compounds 1 and 2 was $78-833 \mu \mathrm{g} / \mathrm{ml}$ and $139-625 \mu \mathrm{g} / \mathrm{ml}$, respectively. The identification of active compounds of methanol extract, which would lead to the discovery of new antimicrobial drugs from the test plant.
\end{abstract}

Keywords: Euphorbia cotinifolia; Isolation; Antibacterial; Minimum Inhibitory Concentration.

(C) 2020 by the authors. This article is an open-access article distributed under the terms and conditions of the Creative Commons Attribution (CC BY) license (https://creativecommons.org/licenses/by/4.0/).

\section{Introduction}

Infectious diseases are emerging at an alarming rate, which is posing a great threat to the population because of the continuous battle with pathogens. Among microbes, pathogenic bacteria are important causal agents for various diseases, which may result in curable illness to fatal conditions leading to death [1]. There is a high increase in the rate of infectious diseases and also antibiotic-resistant microorganisms. Added to this, the side effects of some synthetic antibiotics have led to increasing interest in medicinal plants as a natural alternative to synthetic drugs [2].

Bioactive compounds present in plants are with amazing chemical and functional diversity and make significant contributions to the drug development program. A great deal of research has been done throughout the world to isolate the secondary metabolites from natural 
resources [3]. During recent years considerable attention has been directed towards the exploitation of plant products for control of different microbial infestations [4]. For several years, man has been using plants for the treatment of common infectious diseases, and some of these traditional medicines, even today, are still included as part of the regular treatment of various diseases. Despite, there is an availability of different methods for the discovery of remedy for various diseases. Natural products still remain as one of the best resources of new phytochemical compounds of therapeutic value. The use of different extracts of plant and phytochemicals, both with antimicrobial properties, are of great significance to therapeutic treatments in the medical field. Many medicinal plants are known to be potential in crude drugs as well as a source for novel compounds with antimicrobial activity, with possibly new modes of action [5].

Plants belonging to Euphorbiaceae are rich in for the chemical diversity and known for their isoprenoid and diterpenoids constituents. Many genera of this family has different skeletons of terpenoids such as taglines, ingenanes, jatrophanes, lathyranes, myrstinanes also sesquiterpenoids, flavonoids, and steroids. The compounds that are isolated from the genus Euphorbia extracts have exhibited different biological activities [6]. A study phytochemical and antibacterial activity of ethanolic extracts of Euphorbiaceae members such as Euphorbia milii, Euphorbia hirta, Euphoria pulcherrima, Euphorbia tithymaloides, Euphorbia prostrata against human pathogens reported maximum activity against all the bacterial strains by Euphorbia milii showing a zone of inhibition greater than $10 \mathrm{~mm}$ [7]. Study of antibacterial properties of flavonoids of leaves from different Cactus (Euphorbia caducifolia) against some important bacteria (G+ve or G-ve) and reported that they possess strong antibacterial activity against test pathogenic microbes and revealed $7.83 \pm 0.21 \mathrm{~mm}$ zone of inhibition for free flavonoid [8]. The petroleum ether, methanolic, and aqueous extracts of leaves of Euphorbia hirta recorded antimicrobial activity against B. subtilis, E. coli, S. aureus, and S. cerevisiae, and all the extracts revealed from moderate to significant activity in contrast to standard. The phytochemical analysis of petroleum ether, methanolic, and aqueous extracts revealed the presence of tannins, related polyphenols, terpenes, anthocyanins, alcohols, steroids like Bsitosterol and B-amyrin [9]. The literature reports as shown that euphorbiaceae plants have potent antimicrobial activity. The botanical name of Euphorbia cotinifolia Linn. comes from the word 'cotinus' means 'smoke tree', and 'folia' means 'leaf'. The common name for the plant is a tropical smoke bush, smoke tree spurge, and Caribbean copper plant. E. cotinifolia is a tropical deciduous shrub or small tree with thin leaves that is noted for its attractive burgundyred foliage. Euphorbia genus belongs to the family Euphorbiaceae, which contains at least 2,100 species and is found to be one of the most diverse genera in the plant kingdom [10]. Euphorbia cotinifolia, a tropical shrub, is with numerous medicinal applications. The leaves of the plant had been employed as poison for catching fish by Southern American Indians. The latex is strongly purgative and the leaves have antiviral and molluscicidal properties [11]. Hirota et al. [12], have isolated and characterization of some Ingenol-Esters such as 3-Opropionyl-20-O-(S)-(2'-methyl)butyryl-ingenol, 20- $O$-isobutyryl-ingenol, 3-Opropionyl-20$O$-isobutyryl-ingenol, and 3, 20-O-di-isobutyryl-ingenol from the leaves of $E$. cotinifolia which as piscicidal constituents. Recent research on chemical constituents of E. cotinifolia reported the presence of metalloprotease in the E. cotinifolia latex [13].

Plants are the sources of potent biochemicals, and they are obtained from different parts of the plant. Herbal remedies in traditional folk medicine are largely explored fields for the development of active new drugs for chemotherapy, which help to overcome the growing 
problems of drug resistance and avoiding the problems of the available antibiotics currently. The interest in the possible application of the secondary metabolites for human disease management as increased, which has directed investigation towards the search for new sources of natural products that are biologically active.

This paper describes the isolation, characterization, and the determination of the structure of the newly isolated compounds from E. cotinifolia. The compounds that are newly isolated were evaluated for antimicrobial activity against bacterial pathogens.

\section{Materials and Methods}

\subsection{Plant material.}

Fresh and Healthy leaves of Euphorbia cotinifolia were collected from the surrounding areas. Aqueous and different solvent extracts were prepared from it. A voucher specimen of the plant was deposited in the Herbarium of Department of Studies in Botany, University of Mysore

\subsection{Extraction.}

The test plants were thoroughly washed, shade dried, and powdered by using a warring blender. Soxhlet extraction apparatus was used for extraction. 100g of Powdered leaf material was placed in a porous thimble of the apparatus in the upper chamber. $200 \mathrm{ml}$ of extracting solvent was added in the lower boiling flask. The flask was heated by using a heating mantle controlled by a thermostat. Different solvents based on polarity from low to high in the following order of petroleum ether, chloroform, ethyl acetate, and methanol were filled in the round bottom flask, and the temperature was set based on the boiling point of the solvents. The solvent was heated to reflux and extracted. The material in the thimble was extracted with the different solvents successively till colorless extract was collected on the top of the extractor. The solvent extract collected after was concentrated separately under reduced pressure. After complete evaporation of the solvent from the extract, all solvent extracts were weighed and preserved in brown airtight bottles at $5{ }^{\circ} \mathrm{C}$ until further use.

\subsection{Phytochemical analysis.}

Phytochemical analysis of all the aqueous and solvent extracts was performed for the detection of active secondary metabolites or different constituents such as tannins, alkaloids, flavonoids, terpenoids, steroids, carbohydrates, proteins, and saponins. The dried extracts extracted by the soxhlet apparatus were reconstituted in methanol, and each extract was subjected to standard phytochemical analysis according to the procedure described by Harborne [14].

\subsection{General.}

All the solvents and chemicals utilized in the present experiment were of Analytical Reagent grade. Solvents were used as supplied by commercial sources without any further purification. For the HPLC experiment, HPLC grade solvents were used. Elemental analysis was performed using an Elemental Vario EL elemental analyzer. Column chromatographic separation was performed using Merck 7734 silica gel (60-120 mesh), and the TLC experiment was carried out with pre-coated Merck silica gel 60 PF254 aluminum sheets; the spots obtained 
were visualized under UV light. Agilent 1200 series equipped with UV detector and an inertsil ODS-3 (4.6 $\times 250 \mathrm{~mm}$ ID, $5 \mu \mathrm{m}$, GL science, USA) column was used for HPLC and preparative HPLC experiments. A wavelength was set at $254 \mathrm{~nm}$ in the detector and the oven temperature was maintained at $30^{\circ} \mathrm{C}$. JASCO FTIR-8400 spectrophotometer recorded IR spectra using Nujol mulls. Varian AC 400 spectrometer recorded $1 \mathrm{H} \mathrm{NMR} \mathrm{spectra} \mathrm{in} \mathrm{CDCl}_{3}$ with TMS as the internal standard. From the Varian 1200L model, mass spectrometer spectra of Low-resolution mass were obtained (solvent: $\mathrm{CH}_{3} \mathrm{OH}$ ). Buchi 530 melting point apparatus in open capillaries was used for the determination of melting points and are uncorrected. Thinlayer chromatography was performed (TLC) on pre-coated silica gel plates with $0.25 \mathrm{~mm}$ layer thickness (Merck, Kieselgel 60 F254,). Were used to check the purity of compounds.

\subsection{Isolation.}

The methanol extract ( $4.1 \mathrm{~g}$ ) of E. cotinfolia was applied to a column of silica gel, eluted with a gradient solvent system of $\mathrm{CHCl}_{3}-\mathrm{CH}_{3} \mathrm{OH}$ to give three fractions, E. cotinifolia methanol fraction [ECMF1 (80:20), ECMF2 (50:50) and ECMF3 (20:80)]. The structures of the compounds obtained from methanol extract (ECMF1 and ECMF2) were elucidated by spectroscopic techniques.

\subsection{Human pathogenic bacteria.}

Accurate and Authentic sample cultures of human pathogenic bacteria viz., Bacillus cereus (B. cereus) (MTCC 1272), Bacillus subtilis (B. subtilis) (MTCC 121), Escherichia coli (E. coli) (MTCC 7410), Enterobacter aerogens (Ent. aerogens) (MTCC 7325), Klebsiella pneumoniae (Klb. pneumoniae) (MTCC 7407), Salmonella typhi (S. typhi) (MTCC 733) and Staphylococcus aureus (Staph. aureus) (MTCC 7443) was used as test bacteria and obtained from Microbial Type Culture Collection (MTCC), Chandigarh, India. All the above bacterial samples were further sub-cultured on nutrient agar (NA) medium and frequently cultured. These bacterial cultures were used as test pathogens for the assay.

\subsection{Antibacterial activity.}

Antibacterial activity of the fractions and compounds obtained was assayed by the agar cup diffusion method [15]. On NA medium, $7 \mathrm{~mm}$ cork borer was used to make cups. A $50 \mu 1$ of $24 \mathrm{~h}$ bacterial culture containing $106 \mathrm{CFU} / \mathrm{ml}$ of bacteria was transferred and spread on the solidified media with a sterile swab, which is moistened with the bacterial suspension. The fractions and compounds to be tested were reconstituted in methanol and prepared at a concentration of $100 \mathrm{mg} / \mathrm{ml} .100 \mu \mathrm{l}$ of the fractions and compounds were placed in an individual cup, and methanol of $100 \mu \mathrm{l}$ was placed in the central cup, which was considered as a negative control. All the plates were incubated at $37^{\circ} \mathrm{C}$ for $24 \mathrm{~h}$ and inhibition zone if any around the cups were measured in millimeter. For each treatment, a set of three replicates were maintained, and all assays were repeated twice.

\subsection{Minimum inhibitory concentration (MIC).}

MIC was determined in 96 well sterile flat-bottom microtiter plates based on microdilution assay, which is an automated turbidometric and colorimetric method as described by Das [16]. Test bacterial Inoculum was prepared from $24 \mathrm{~h}$ cultured bacteria, and a 
suspension was made in sterile/ saline water and adjusted to $0.5 \mathrm{McFarland}$ standard solution turbidity.

E. cotinifolia methanol fractions and compounds were diluted to a concentration of 100 $\mathrm{mg} / \mathrm{ml}$, which was used as a stock solution. The 96 well microtiter plates were prepared by transferring $200 \mu \mathrm{l}$ of broth and $100 \mu \mathrm{l}$ of the fractions/compound to the first well. A two-fold serial dilution was made in the row up to 12 well, and final concentrations from well 1 to 12 were $5-0.019 \mathrm{mg} / \mathrm{ml}$. A $10 \mu \mathrm{l}$ inoculum suspension of each bacterial strain was added to each well. The wells containing solvent and nutrient broth with inoculum served as a negative control. The plates were incubated at $37^{\circ} \mathrm{C}$ for $24 \mathrm{~h}$, and the absorbance was measured at 620 $\mathrm{nm}$ using a microplate reader (LT4000, LABTECH Instruments, UK). The minimum concentration that inhibited visible growth of the test bacteria was considered as the MIC based on the readings.

The minimum inhibitory concentration was also detected by adding TTC (10 $\mu \mathrm{l} /$ well $)$ (2, 3, 5-triphenyl tetrazolium chloride) dissolved in water (TTC $2 \mathrm{mg} / \mathrm{ml}$ ) and incubated under favorable conditions for $30 \mathrm{~min}$ [ 17]. The presence of a Viable organism reduced the dye to pink color. The minimum concentration at which there was a color change was taken as the MIC value. All MIC tests were repeated in triplicates.

\section{Results and Discussion}

\subsection{Phytochemical analysis.}

The results of the phytochemical analysis of E. cotinifolia recorded the presence of flavonoids, terpenoids, tannins, steroids, and glycosides in methanol extracts. Steroids, glycosides, and carbohydrates were present in chloroform and petroleum ether extracts. The results obtained by following the above phytochemical tests on E. cotinifolia are given in Table 1.

Table 1. Phytochemical analysis of different solvent extracts of E. cotinifolia.

\begin{tabular}{l|c|c|c|c}
\multirow{2}{*}{$\begin{array}{l}\text { Phytochemical } \\
\text { compounds }\end{array}$} & \multicolumn{4}{|c}{ Extracts } \\
\cline { 2 - 5 } Alkaloids & Petroleum ether & Chloroform & Ethyl acetate & Methanol \\
\hline Flavonoids & - & - & - & - \\
\hline Terpenoids & - & - & + & + \\
\hline Tannins & - & - & + & + \\
\hline Steroids & - & - & + & + \\
\hline Glycosides & + & + & + & + \\
\hline Carbohydrates & + & + & - & - \\
\hline Proteins & + & - & - & - \\
\hline $\begin{array}{l}\text { Saponins } \\
+=\text { Present; - Absent }\end{array}$ & - & - & - & -
\end{tabular}

\subsection{Characterization of active compounds of E. cotinifolia.}

Preliminary phytochemical analysis of methanol extracts of E. cotinifolia recorded the presence of terpenoids, tannins, flavonoids, and steroids. The structure of compounds of $E$. cotinifolia was elucidated by spectroscopic methods (IR, ${ }^{1} \mathrm{H}$ NMR, ${ }^{13} \mathrm{C}$ NMR, and MS) ( Fig 2). The IR spectrum displayed absorption bands indicating hydroxy $\left(3364 \mathrm{~cm}^{-1}\right)$ and carbonyl $\left(1715,1670\right.$, and $1638 \mathrm{~cm}^{-1}$ ) functionalities ( Fig 3). The ${ }^{1} \mathrm{H}$ NMR spectra of compound 1 revealed that the presence of hydroxyl and methyl ester groups, which displayed signals at 3.35 $(\mathrm{s}, 1 \mathrm{H})$ and $3.68(\mathrm{~s}, 3 \mathrm{H})$, respectively. The spectrum displayed singlet at $1.28(\mathrm{~s}, 6 \mathrm{H})$ and 1.81 $(\mathrm{s}, 3 \mathrm{H})$ showed the presence of three methyl groups. In addition, a triplet peak at $0.89(\mathrm{t}, 3 \mathrm{H})$ 
indicated the presence of another methyl group, which is linked to the aliphatic carbon chain. The one singlet at $5.40(\mathrm{~s}, 1 \mathrm{H})$ and a doublet at $5.80(\mathrm{~d}, 1 \mathrm{H})$ were due to the olefin protons in the compound. The ${ }^{13} \mathrm{C}$ NMR of compound 1 revealed the presence of 27 signals, including three peaks at $\delta 159,164$, and 190, which were assigned to the carbonyl group ( Fig 1). The mass spectrum recorded a molecular ion peak at $\mathrm{m} / \mathrm{z} 472$ correspondings to its molecular formula $\mathrm{C}_{28} \mathrm{H}_{40} \mathrm{O}_{6}$.

The methanol extract was applied to a silica gel column, leading to the isolation of a new compound 1. Compound 1 was obtained as a pale yellow gum from $\mathrm{CHCl}_{3}-\mathrm{CH}_{3} \mathrm{OH}$ (80:20) elute. The results obtained from the analytical and different spectral studies are given below: Compound 1. Anal. calc. for $\left(\mathrm{C}_{28} \mathrm{H}_{40} \mathrm{O}_{6}\right)$ : C 71.16; $\mathrm{H}$ 8.53. found: C 71.13; H 8.51. IR (nujol, $\left.\mathrm{cm}^{-1}\right): 3364,1715,1670,1638 .{ }^{1} \mathrm{H} \mathrm{NMR}\left(300 \mathrm{MHz}, \mathrm{CDCl}_{3}\right) \delta: 0.80(\mathrm{~m}, 2 \mathrm{H}), 0.90(\mathrm{t}$, $3 \mathrm{H}), 1.28(\mathrm{~s}, 6 \mathrm{H}), 1.50-1.80(\mathrm{bm}, 12 \mathrm{H}), 1.83(\mathrm{~s}, 3 \mathrm{H}), 2.52(\mathrm{~m}, 3 \mathrm{H}), 3.10(\mathrm{~s}, 2 \mathrm{H}), 3.35(\mathrm{bs}, 1 \mathrm{H})$, $3.68(\mathrm{~s}, 3 \mathrm{H}), 3.86(\mathrm{~d}, 1 \mathrm{H}), 4.73,(\mathrm{~d}, 1 \mathrm{H}), 5.40(\mathrm{~s}, 1 \mathrm{H}), 5.80(\mathrm{~d}, 1 \mathrm{H}),{ }^{13} \mathrm{C} \mathrm{NMR}\left(300 \mathrm{MHz}, \mathrm{CDCl}_{3}\right)$ $\delta: 14,21,23,24,25,26,27,32,35,36,38,39,40,44,45,46,50,63,73,75,125,130,139$, 146, 159, 164, 190. MS, m/z: $472\left(\mathrm{M}^{+}\right)$.

Based on the above readings, name of the compound 1( Fig 7). is given as 5-hydroxy4-(2-methoxy-2-oxoethyl)-1,1,7-trimethyl-11-oxo-1a,2,5,5a,6,9,10,10a-octahydro-1H-2,8amethanocyclopenta [a]cyclopropa[e][10]annulen-6-yl heptanoate

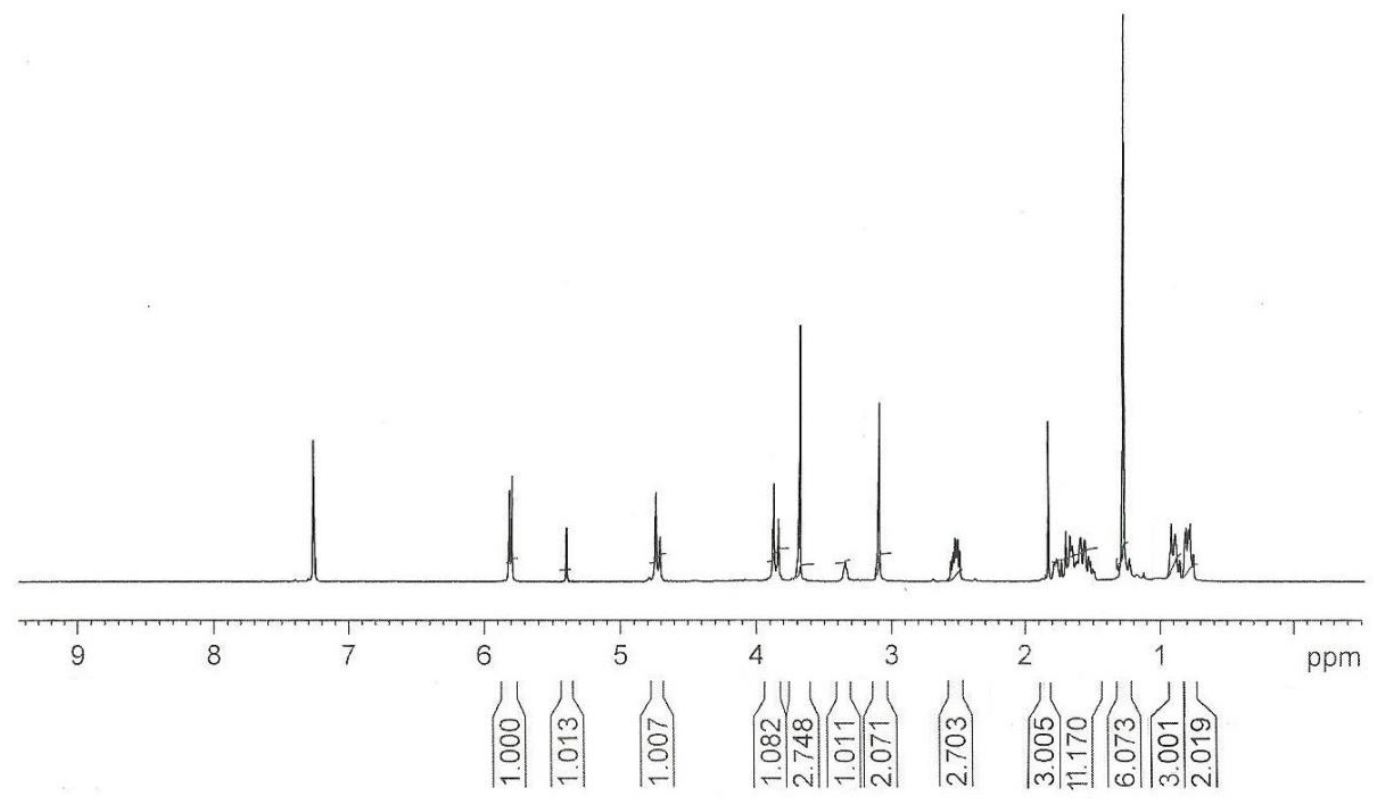

Figure 1. ${ }^{1} \mathrm{H}$ NMR spectrum of Compound 1 of E. cotinifolia.

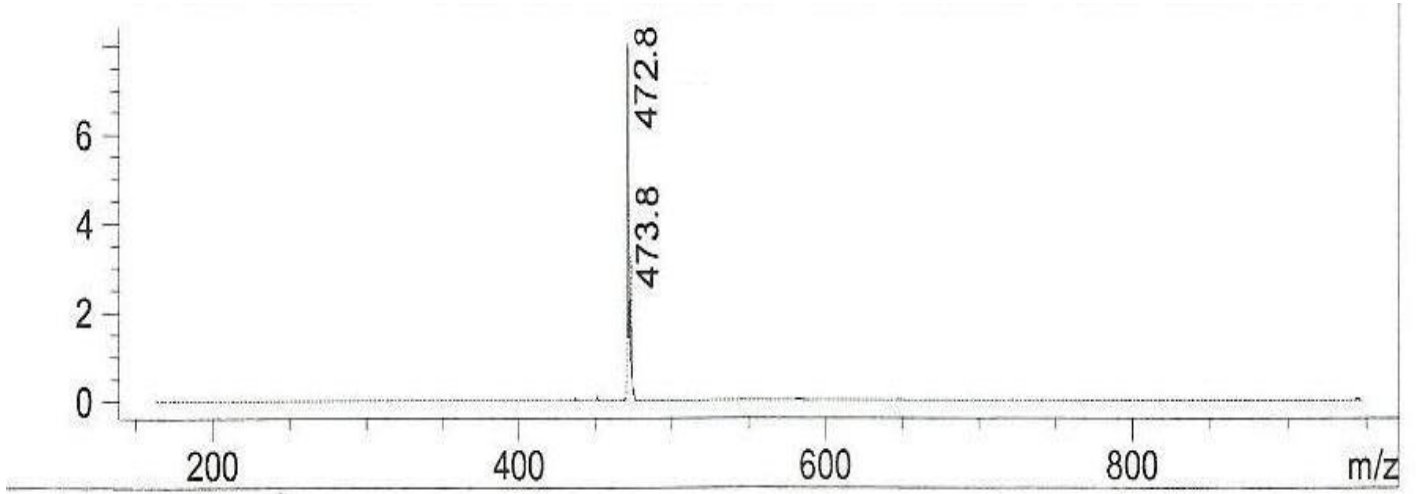

Figure 2. Mass spectrum of Compound 1 of E. cotinifolia. 


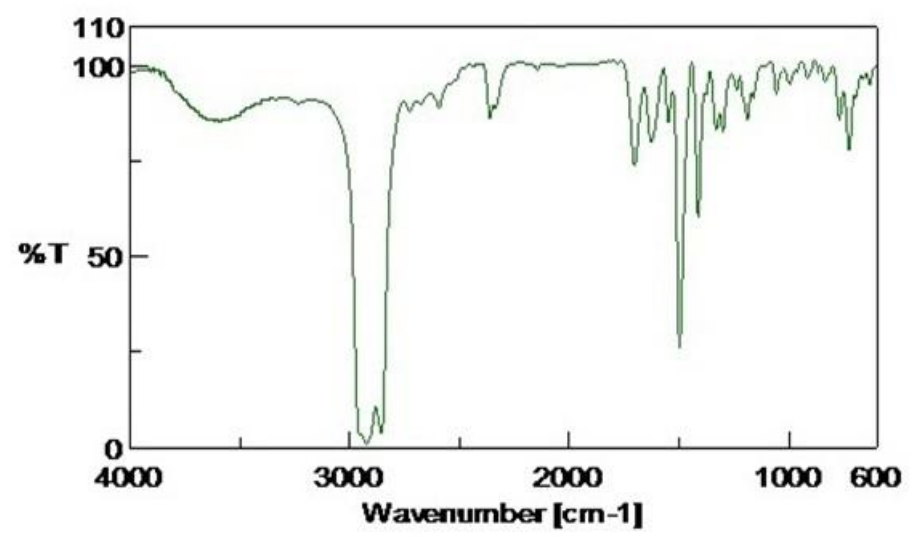

Figure 3. IR spectrum of Compound 1 of E. cotinifolia.

The methanol extract was fractionated by column chromatography and preparative TLC to yield new terpenoid (compound 2).

The isolated compound 2 can be regarded as closely related to the structure of compound 1 and differed only in the length of the alkyl chain, one methyl, and the carbonyl group. Compound 2 was isolated as a pale yellow gum. The mass spectra displayed the molecular ion peak at (M+1) 431, indicating the molecular formula of $\mathrm{C}_{26} \mathrm{H}_{38} \mathrm{O}_{5}$ ( Fig 5). The IR spectrum showed absorption bands of hydroxyl $\left(3381 \mathrm{~cm}^{-1}\right)$ and carbonyl $\left(1716,1670 \mathrm{~cm}^{-}\right.$ $\left.{ }^{1}\right)$ groups( Fig 6). The ${ }^{1} \mathrm{H}-\mathrm{NMR}$ spectrum showed two methyl singlet at $\delta 0.99(\mathrm{~s}, 6 \mathrm{H})$, one methyl triplet at $\delta 0.90(\mathrm{t}, 3 \mathrm{H})$, and one broad singlet at $\delta 3.10(\mathrm{~s}, 1 \mathrm{H})$ was the characteristic of a hydroxyl group, respectively. The presence of a methoxy group was exhibited by a proton signal at $\delta 3.67(3 \mathrm{H}, \mathrm{s})$. The ${ }^{13} \mathrm{C}$ NMR spectrum exhibited peaks for 25 carbons, which included a carbonyl peak at $\delta 171.4$ and 173.1. ( Fig 4). The structure of this compound was identified by physical and spectroscopic data measurement. Characteristic analytical and spectral data of compound 2 are given in the following paragraph: Compound 2. Anal. calc. for $\left(\mathrm{C}_{26} \mathrm{H}_{38} \mathrm{O}_{5}\right)$ : $\mathrm{C}$ 72.53; H 8.90. found: C 72.49; H 8.93. IR (nujol, $\left.\mathrm{cm}^{-1}\right)$ : 3381, 1716, $1670,{ }^{1} \mathrm{H} \mathrm{NMR}(300 \mathrm{MHz}$, $\left.\mathrm{CDCl}_{3}\right) \delta: 0.18(\mathrm{~m}, 1 \mathrm{H}, \mathrm{CH}), 0.21(\mathrm{~d}, 1 \mathrm{H}, \mathrm{CH}), 0.90\left(\mathrm{t}, 3 \mathrm{H}, \mathrm{CH}_{3}\right), 0.99\left(\mathrm{~s}, 6 \mathrm{H}, \mathrm{CH}_{3}\right), 1.20(\mathrm{~d}$, $\left.2 \mathrm{H}, \mathrm{CH}_{2}\right), 1.29\left(\mathrm{~m}, 2 \mathrm{H}, \mathrm{CH}_{2}\right), 1.30\left(\mathrm{t}, 2 \mathrm{H}, \mathrm{CH}_{2}\right), 1.31\left(\mathrm{~m}, 2 \mathrm{H}, \mathrm{CH}_{2}\right), 1.38\left(\mathrm{~m}, 2 \mathrm{H}, \mathrm{CH}_{2}\right), 1.64$ (m, 2H, $\left.\mathrm{CH}_{2}\right), 2.15(\mathrm{t}, 1 \mathrm{H}, \mathrm{CH}), 2.35\left(\mathrm{t}, 2 \mathrm{H}, \mathrm{CH}_{2}\right), 2.58(\mathrm{t}, 1 \mathrm{H}, \mathrm{CH}), 2.92\left(\mathrm{~s}, 2 \mathrm{H}, \mathrm{CH}_{2}\right), 3.10$ (bs, $1 \mathrm{H}, \mathrm{OH}), 3.67\left(\mathrm{~s}, 3 \mathrm{H}, \mathrm{OCH}_{3}\right), 4.74(\mathrm{t}, 1 \mathrm{H}, \mathrm{CH}), 5.60(\mathrm{~d}, 3 \mathrm{H},=\mathrm{C}-\mathrm{H}) .{ }^{13} \mathrm{C}$ NMR $(300 \mathrm{MHz}$, $\left.\mathrm{CDCl}_{3}\right) \delta: 14.1,18.6,22.3,22.4,25.8,26.2,26.8,28.7,31.1,34.3,35.5,36.8,37.7,52.0,130.0$, 136.4, 141.1, 143.7, 171.4, 173.1. MS, m/z: $431(\mathrm{M}+1)$.

Based on the above data, name of the compound 2( Fig 7). is given as 5-hydroxy-4-(2methoxy-2-oxoethyl)-1,1-dimethyl-1a,2,5,5a,6,9,10,10a-octahydro-1H-2,8amethanocyclopenta[a] cyclopropa [e][10]annulen-6-yl hexanoate.

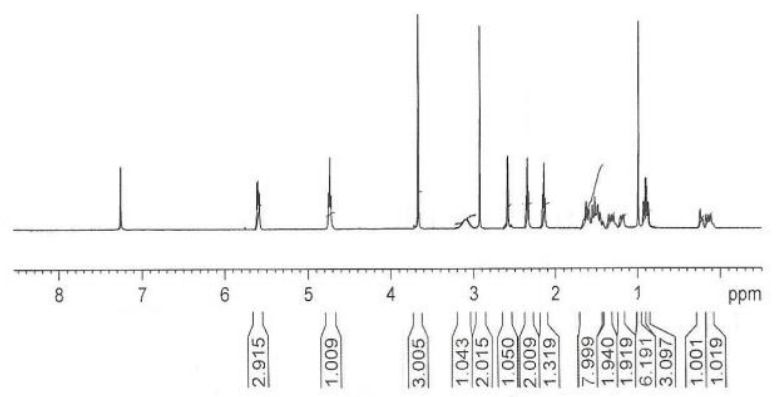

Figure 4. ${ }^{1} \mathrm{H}$ NMR spectrum of Compound 2 of E. cotinifolia. 


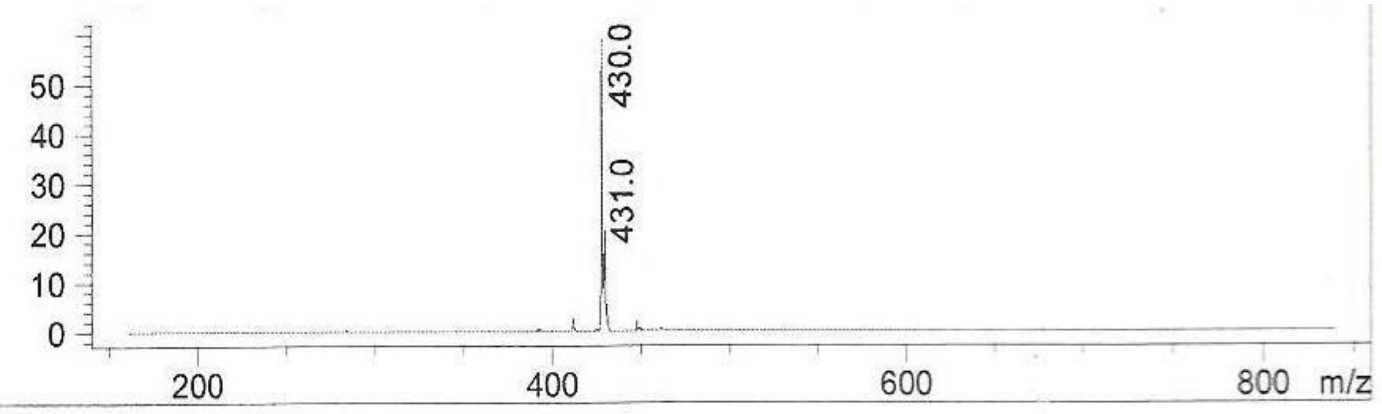

Figure 5. Mass spectrum of Compound 2 of E. cotinifolia.

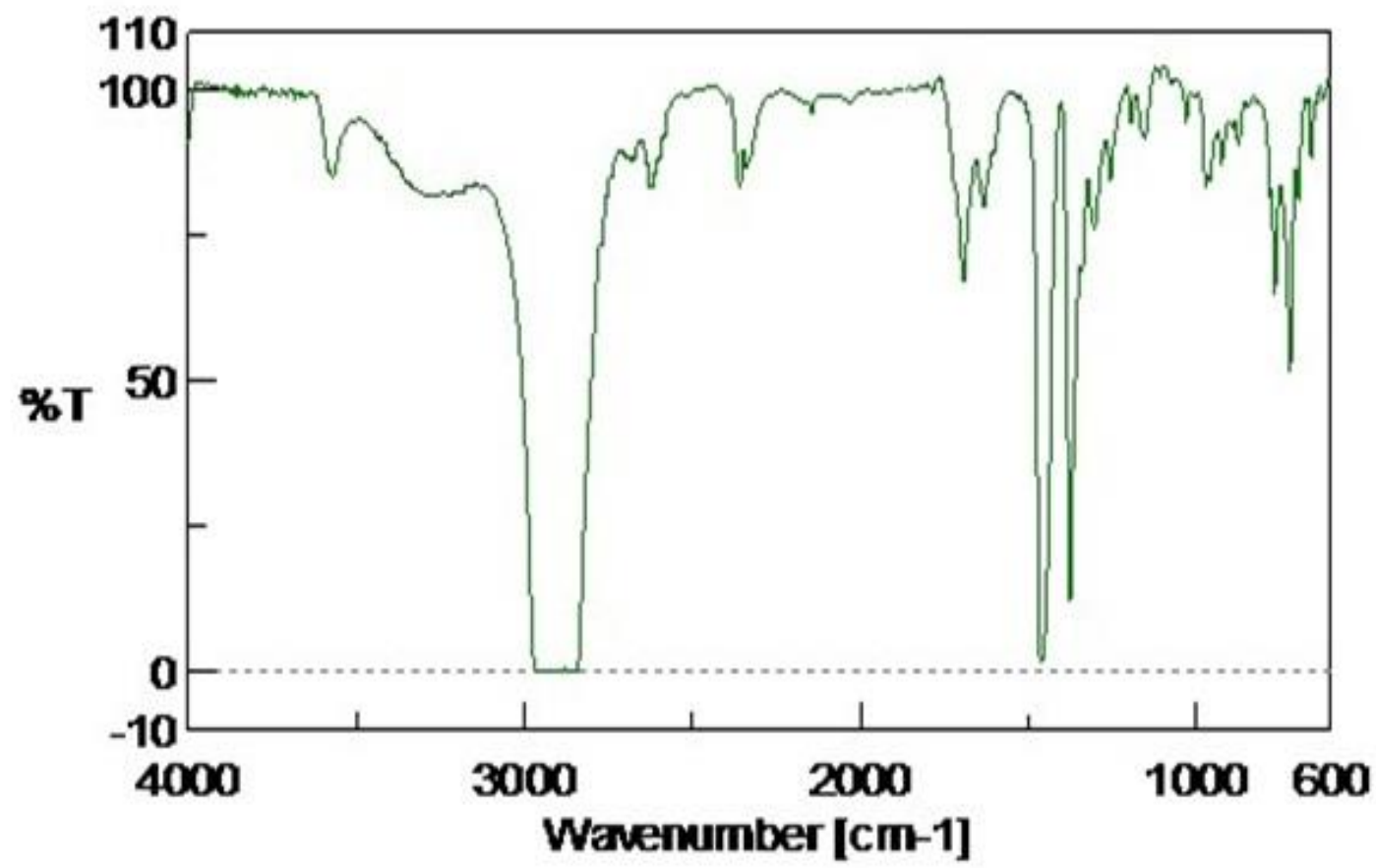

Figure 6. IR spectrum of Compound 2 of E. cotinifolia.

With the help of analytical and spectral data, the following structures (Fig. 7) are proposed for the newly isolated compounds 1 and 2 .
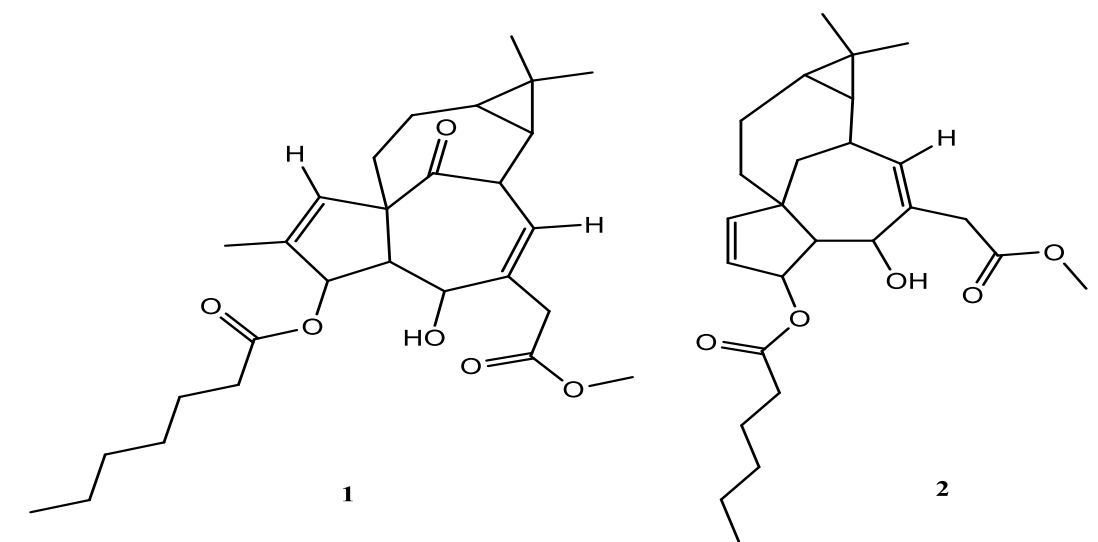

Figure 7. Structures of newly isolated Compounds 1 and 2 of E. cotinifolia.

\subsection{Antibacterial activity.}

The antibacterial activity results of aqueous and different solvent extracts of $E$. cotinifolia against the test bacteria are presented in Table 2. Among the solvent extracts, ethyl acetate and methanol showed significant activity, while negligible activity was found with 
chloroform extract. The inhibition range was recorded between $10-14 \mathrm{~mm}$ and $12-17$ for ethyl acetate and methanol extracts, respectively E. aerogenes. B. subtilis and K. pneumoniae, were highly susceptible to methanol extract, recording the maximum zone of inhibition of 17 $\mathrm{mm}$. Ethyl acetate extract showed a uniform inhibition zone, which was in the range of 10-14 $\mathrm{mm}$ for all the tested bacteria. The inhibition zone of crude methanol extract was slightly lesser than that of streptomycin, a standard antibiotic. The MIC for different test bacteria ranged from $0.312-1.25 \mathrm{mg} / \mathrm{mL}$ for methanol and ethyl acetate extracts. The minimum MIC concentration was $0.312 \mathrm{mg} / \mathrm{mL}$ for both the extracts recorded for B. subtilis. (Table 3).

Table 2. Antibacterial activity of different extracts of $E$. cotinifolia against human pathogenic bacteria (in $\mathrm{mm}$ ).

\begin{tabular}{l|c|c|c|c|c|c} 
Bacteria & Aqueous & Petroleum ether & Chloroform & Ethyl acetate & Methanol & Streptomycin \\
\hline Bacillus cereus & 0.00 & - & $8.75 \pm 0.47^{\mathrm{b}}$ & $11.25 \pm 0.47^{\mathrm{ab}}$ & $12.25 \pm 0.50^{\mathrm{c}}$ & $21.0 \pm 0.40^{\mathrm{bc}}$ \\
\hline Bacillus subtilis & 0.00 & $8.25 \pm 0.2^{\mathrm{a}}$ & $8.50 \pm 0.28^{\mathrm{b}}$ & $12.75 \pm 0.62^{\mathrm{a}}$ & $17.25 \pm 0.62^{\mathrm{bc}}$ & $20.75 \pm 0.47^{\mathrm{bc}}$ \\
\hline Escherichia.coli & 0.00 & - & $8.50 \pm 0.28^{\mathrm{b}}$ & $10.75 \pm 0.25^{\mathrm{b}}$ & $13.5 \pm 0.64^{\mathrm{a}}$ & $23.75 \pm 0.47^{\mathrm{a}}$ \\
\hline Enterobacter aerogenes & 0.00 & - & $10.25 \pm 0.2^{\mathrm{a}}$ & $13.0 \pm 0.57^{\mathrm{a}}$ & $17.25 \pm 0.62^{\mathrm{a}}$ & $21.25 \pm 0.62^{\mathrm{bc}}$ \\
\hline Klebsiella pneumoniae & 0.00 & $8.0 \pm 0.40^{\mathrm{a}}$ & $8.75 \pm 0.25^{\mathrm{b}}$ & $12.75 \pm 0.25^{\mathrm{a}}$ & $17.0 \pm 0.40^{\mathrm{a}}$ & $19.75 \pm 0.62^{\mathrm{c}}$ \\
\hline Salmonella typhi & 0.00 & - & $8.25 \pm 0.25^{\mathrm{b}}$ & $11.5 \pm 0.28^{\mathrm{ab}}$ & $16.0 \pm 0.40^{\mathrm{a}}$ & $22.5 \pm 0.28^{\mathrm{ab}}$ \\
\hline Staphylococcus aureus & 0.00 & - & $0.00 \pm 0$ & $10.75 \pm 0.25^{\mathrm{b}}$ & $15.5 \pm 0.28^{\mathrm{ab}}$ & $19.25 \pm 0.47^{\mathrm{c}}$
\end{tabular}

Values are the means of four independent replicates. Figures followed by different letters in columns differ significantly when subjected to Tukey $(\mathrm{P}<0.05)$. - means no activity.

Table 3. MIC of ethyl acetate extract and methanol $(\mathrm{mg} / \mathrm{mL})$ of E. cotinifolia against some human pathogenic bacteria.

\begin{tabular}{l|c|c|c|c|c|c|c} 
Bacteria & $\begin{array}{c}\text { Bacillus } \\
\text { cereus }\end{array}$ & $\begin{array}{c}\text { Bacillus } \\
\text { subtilis }\end{array}$ & $\begin{array}{c}\text { Escherichia } \\
\text { coli }\end{array}$ & $\begin{array}{c}\text { Enterobacter } \\
\text { aerogenes }\end{array}$ & $\begin{array}{c}\text { Klebsiella } \\
\text { pneumoniae }\end{array}$ & $\begin{array}{c}\text { Salmonella } \\
\text { typhi }\end{array}$ & $\begin{array}{c}\text { Staphylococcus } \\
\text { aureus }\end{array}$ \\
\hline MIC of methanol & 1.25 & 0.312 & 1.25 & 0.625 & 0.625 & 0.312 & 0.312 \\
\hline MIC of ethyl acetate & 1.25 & 0.312 & 0.625 & 0.312 & 0.625 & 0.625 & 0.625
\end{tabular}

The three fractions obtained from methanol extract of E. cotinifolia, showed activity for all the human pathogenic bacteria. The range of inhibition zone against human pathogenic bacteria was $15.25-19.50 \mathrm{~mm}, 13.50-19.25 \mathrm{~mm}, 12-18.50 \mathrm{~mm}, 15-20 \mathrm{~mm}$, and 13.50-21.25 $\mathrm{mm}$ in ECMF1, ECMF2, ECMF3, compounds 1 and 2, respectively (Table 4). The MIC of the compounds 1 and 2 against human pathogens was $78-833 \mu \mathrm{g} / \mathrm{ml}$ and $139-625 \mu \mathrm{g} / \mathrm{ml}$, respectively (Table 5). The inhibition zones exhibited by the fractions were equal to that of methanol extract. The inhibition zone measured for the new compounds was good but slightly lesser than that of its crude extract.

Table 4 Antibacterial activity of Methanol Fractions and compounds 1 and 2 of E. cotinifolia against human pathogenic bacteria (in $\mathrm{mm}$ ).

\begin{tabular}{l|l|l|l|l|l|l|l|l} 
Bacteria & $\begin{array}{l}\text { Solvent } \\
\text { control }\end{array}$ & ECMF1 & ECMF2 & ECMF3 & Compound 1 & Compound 2 & Streptomycin & Gentamicin \\
\hline B. cerus & 0.00 & $16.00 \pm 0.00$ & $18.50 \pm 0.50$ & $17.50 \pm 0.50$ & $15.00 \pm 0.00$ & $17.00 \pm 0.50$ & $21.00 \pm 0.40$ & $24.30 \pm 0.33$ \\
\hline B. subtilis & 0.00 & $18.75 \pm 1.15$ & $19.25 \pm 0.57$ & $18.50 \pm 0.57$ & $18.67 \pm 0.50$ & $19.00 \pm 0.57$ & $20.75 \pm 0.47$ & $29.30 \pm 0.88$ \\
\hline E. coil & 0.00 & $16.00 \pm 0.00$ & $13.50 \pm 0.57$ & $14.25 \pm 0.57$ & $16.50 \pm 0.00$ & $13.50 \pm 0.57$ & $23.75 \pm 0.47$ & $22.00 \pm 0.57$ \\
\hline Ent. aerogens & 0.00 & $19.50 \pm 0.50$ & $22.00 \pm 0.57$ & $17.50 \pm 0.57$ & $20.00 \pm 0.50$ & $21.25 \pm 0.37$ & $21.25 \pm 0.62$ & $23.60 \pm 0.88$ \\
\hline $\begin{array}{l}\text { Klb. } \\
\text { pneumonia }\end{array}$ & 0.00 & $18.00 \pm 1.00$ & $15.75 \pm 1.15$ & $12.00 \pm 0.57$ & $18.50 \pm 1.00$ & $16.00 \pm 1.15$ & $19.75 \pm 0.62$ & $22.60 \pm 0.33$ \\
\hline S. typhi & 0.00 & $15.25 \pm 0.57$ & $14.50 \pm 0.57$ & $14.00 \pm 0.00$ & $17.00 \pm 1.00$ & $15.00 \pm 0.57$ & $22.50 \pm 0.28$ & $23.60 \pm 0.66$ \\
\hline $\begin{array}{l}\text { Staph. aureus } \\
\text { Values are the mean of three independent replicates. } \pm \text { Standard Deviation }\end{array}$ & 0.00 & $17.00 \pm 0.00$ & $14.25 \pm 0.57$ & $13.50 \pm 1.50$ & $17.50 \pm 0.00$ & $14.62 \pm 0.57$ & $19.25 \pm 0.47$ & $30.30 \pm 0.33$ \\
\end{tabular}

Table 5. MIC of Methanol Fractions and Compounds 1 and 2 of E. cotinifolia against human pathogenic bacteria (in $\mu \mathrm{g} / \mathrm{ml}$ ).

\begin{tabular}{l|l|l|l|l} 
Bacteria & ECMF1 & ECMF2 & Compound 1 & Compound 2 \\
\hline B. cereus & 529 & 833 & 625 & 729 \\
\hline B. subtilis & 208 & 156 & 169 & 104 \\
\hline E. coil & 520 & 625 & 729 & 416 \\
\hline Ent. aerogens & 78 & 169 & 110 & 91
\end{tabular}




\begin{tabular}{l|l|l|l|l} 
Bacteria & ECMF1 & ECMF2 & Compound 1 & Compound 2 \\
\hline Klb. pneumonia & 156 & 140 & 156 & 212 \\
\hline S. typhi & 625 & 416 & 833 & 625 \\
\hline Staph. aureus & 208 & 315 & 416 & 312 \\
Values are the mean of three independent replicates. \pm Standard Deviation
\end{tabular}

\subsection{Discussion.}

Euphorbia is the largest genus belonging to the family Euphorbiaceae comprising about 2000 known species. Several researchers have shown the antibacterial and antioxidant activity of different Euphorbia sp., and the reports support the usage of these plants for the treatment of various diseases in traditional medicine. The antibacterial activity of ethanol, chloroform, and hexane of extract of leaves of Euphorbia hirta extract was studied against some test bacteria and fungi such as Streptococcus mutans, Clostridium absonum, and Escherichia coli by disc diffusion method. The ethanolic leaf extract of Euphorbia hirta recorded the maximum zone of inhibition against Clostridium (32 mm) [9; 18; 19]. A study on antimicrobial activity and phytochemical screening of Euphorbia helioscopia reported the potential of the aqueous extract against Escherichia coli, and ethanol extract showed an inhibition zone against Bacillus subtilus $(36 \mathrm{~mm})$ and Klebsiella pneumonia $(33 \mathrm{~mm}$ ) [ 20]. Phytochemical studies of Euphorbia milii showed the presence of cardiac glycosides, steroids/phytosterols, anthocyanin, terpenoids, flavonoids and tannins, and the hexane extracts in the concentration of $5 \mu \mathrm{g} / \mathrm{ml}$, have shown considerable inhibition zone against Bacillus subtilis, Bacillus megaterium, Staphylococcus aureus, Entrococci, Escherichia coli, Proteus vulgaris and Pusodomonas aeruginosa [21].

The genus Euphorbia contains the well-known diterpenoids such as jatrophene, lathyrane and myrisinane tigliane, ingenane, daphnane, segetane sesquiterpenoids, flavonoids (ruten kaempferol, myricetri, quercetin derivatives), volatile compounds (terpinene, linalool, $\alpha$-terpinol), tannins (euphorbins), triterpenoids (lupeol, betulin) and phytosterols ( $\beta$-sitosterol) were the constituents isolated from different parts of the Euphorbia species. Many of the compounds have been investigated for their toxicity or their potential activity [ 22, 23, 24]. The mode of toxicity of tannins on microorganisms operates either by direct action on the microbial membrane or by metal ion depletion [25] In the present investigation. Two more diterpenoids have been isolated from E. cotinifolia, which have exhibited potent antibacterial activity against the test bacteria.

The literature review of $E$. cotinifolia has revealed the isolation and characterization of new ingenol esters from methanolic extract [26], which possess piscicidal constituents, two new ellagitannins, and a trigalloylglucoseyl kaempferol from E. cotinifolia extract possessed antitumor and antioxidant activity indicating its potential. A study by Runyoro et al. [27] reported the antifungal activity, and brine shrimp lethality of the latex, methanolic leaf and stem bark extracts of Euphorbia cotinifolia and extracts inhibited Trichophytonmentagrophytes and Aspergillus niger with inhibition zones of 17 and $15 \mathrm{~mm}$, respectively, for leaves and 9 $\mathrm{mm}$ for both fungi in the case of stem bark extracts, the leaf extract also inhibited Trichophyton rubrum $(12 \mathrm{~mm})$, and the MICs ranged from $2.5-5 \mathrm{mg} / \mathrm{ml}$.

In the present study, biologically active two diterpenes were isolated, and the structures of the two new diterpenoids isolated from E. cotinifolia were closely related to an ingenol ester in which the alkyl chain is differing in the present structure of the active compound of methanol extract. Terpenoids are made up of isoprene units, but the mode of action of terpenes is not 
completely understood and is believed to involve membrane disruption by their lipophilic compound. Polycyclic diterpenoids with tigliane (phorbol esters), ingenane (ingenol esters), jatrophene, and laryprane skeletons are among the most studied diterpenoids isolated from Euphorbia species[12]. The chemical composition of essential oils from Euphorbia species revealed the presence of more than 80 phytochemicals, mainly oxygenated sesquiterpenes and sesquiterpenes hydrocarbons. At the same time, Euphorbia extracts contain secondary metabolites such as sesquiterpenes, diterpenes, sterols, flavonoids, and other polyphenols. The extracts and secondary metabolites from Euphorbia plants may act as active principles of medicines for the treatment of many human ailments, mainly inflammation, cancer, and microbial infections [28]. Thus, in the present study, two new terpenoids from methanol extract of $E$. cotinifolia have been reported with an antibacterial activity, which could be a source of new active molecules for drug development.

Currently, there is an emerging interest in plant-based or herbal medicine throughout the world. The utilization of naturally occurring phytochemicals from plants, which checks the growth of unwanted microorganisms, would be a natural and ecologically sound method and will have a prominent role in the development of future commercial drugs.

\section{Conclusions}

Currently, there is an emerging interest in plant-based or herbal medicine throughout the world. The utilization of naturally occurring phytochemicals from plants, which checks the growth of unwanted microorganisms, would be a natural and ecologically sound method and will have a prominent role in the development of future commercial drugs.

\section{Funding}

This research received no external funding.

\section{Acknowledgments}

One of the authors B. Jayalakshmi is thankful to the University Grants Commission, New Delhi, for awarding the FIP-Teacher Fellowship and the Department of Collegiate Education, Govt. of Karnataka, Bangalore, and also the University of Mysore, Mysore for providing the laboratory facilities.

\section{Conflicts of Interest}

The authors declare no conflict of interest.

\section{References}

1. Fauci, A.S.; Touchette, N.A.; Folkers, G.K. Emerging infectious diseases: a 10-year perspective from the National Institute of Allergy and Infectious Diseases. Emerg Infect Dis 2005, 11, 519-525, https://doi.org/10.3201/eid1104.041167.

2. Alanis, A.J. Resistance to Antibiotics: Are We in the Post-Antibiotic Era? Archives of Medical Research 2005, 36, 697-705, https://doi.org/10.1016/j.arcmed.2005.06.009.

3. Cowan, M.M. Plant Products as Antimicrobial Agents. Clinical Microbiology Reviews 1999, 12, 564582, https://doi.org/10.1128/CMR.12.4.564.

4. Vaidya, A.D.B.; Devasagayam, T.P.A. Current Status of Herbal Drugs in India: An Overview. Journal of Clinical Biochemistry and Nutrition 2007, 41, 1-11, https://doi.org/10.3164/jcbn.2007001.

5. Alagesaboopathi, C. Antimicrobial screening of selected medicinal plants in Tamilnadu, India. African Journal of Microbiology Research 2011, 5, 617-621. 
6. Evans, F.; Taylor, S. Pro-inflammatory, tumor promoting and antitumor diterpene of the plant families' Euphorbiaceae and Thymelaeaceae. In: Herz, WGrisebach H and Kirby, G (Eds). Progress in the Chemistry of Organic Natural Products Springer-Verlag, New York 1983, 44, 1-99, https://doi.org/10.1007/978-37091-8714-2.

7. Maneesha, S.; Sudha. Evaluation of Phytochemical and Antibacterial Activity of Euphorbiaceae Members Against Human Pathogens. International Journal of Recent Scientific Research Research 2018, 9, 2853428538.

8. Singariya, P.; Mourya, K.K.; Kumar, P. Comparative study of antibacterial properties of flavonoids of leaves from different cactus, perennial grasses and medicinal plant. Asian Journal of Pharmaceutical Research and Development 2018, 6, 32-41.

9. Gupta, R.; Gupta, J. Investigation of antimicrobial activity of euphorbia hirta leaves. International Journal of pharma and Bio Sciences 2019, 9, 32-37. https://dx.doi.org/10.22376/ijpbs/lpr.2019.9.3.P32-37.

10. Webster, G. Synopsis of the genera and suprageneric taxa of Euphorbiaceae. Annal Miss Bot Gard. 1994, 81, 33-144, https://doi.org/10.2307/2399909.

11. Pereira, E.M.; Gomes, R.T.; Freire, N.R.; Aguiar, E.G.; Brandão, M.; Santos, V.R. In vitro antimicrobial activity of Brazilian medicinal plant extracts against pathogenic microorganisms of interest to dentistry. Planta Med 2011, 77, 401-404, https://doi.org/10.1055/s-0030-1250354.

12. Hirota, M.; Ohigashi, H.; Oki, Y.; Koshimizu, K. New Ingenol-Esters as Piscicidal Constituents of Euphorbia cotinifolia L. Agricultural and Biological Chemistry 1980, 44, 1351-1356, https://doi.org/10.1271/bbb1961.44.1351.

13. Kumar, R.; Singh, K.A.; Tomar, R.; Jagannadham, M.V. Biochemical and spectroscopic characterization of a novel metalloprotease, cotinifolin from an antiviral plant shrub: Euphorbia cotinifolia. Plant Physiology and Biochemistry 2011, 49, 721-728, https://doi.org/10.1016/j.plaphy.2011.03.016.

14. Harborne, J.B. Phytochemical Methods. Chapman and Hall Publications, London, 1998; https://doi.org/10.1007/978-94-009-5570-7_1.

15. Perez, C.; Paul, M.; Bazerque, P. An antibiotic assay by agar well diffusion method. Acta Bio Med Exp 1990, 15, 113-115.

16. Das, K.; Tiwari, R.; Shrivastava, D.; Bilaspur, B.C. Techniques for evaluation of medicinal plant products as antimicrobial agent: Current methods and future trends. J. Med. Plant Res 2010, 4, 104-111.

17. Qaiyami S. Macro and Microdilution methods of antimicrobial susceptibility Testing. In: Antimicrobial Susceptibility Testing Protocols. Schwalbe, R.; Steele-Moore, L.; Goodwin, A.C. editors. New York, Taylor \& Francis Group; 2007; pp.75-81.

18. Divya, G.; Mukesh, K.; Vishal, G. An in vitro investigation of antimicrobial efficacy of euphorbia hirta and murraya koenigii against selected pathogenic microorganisms. Asian Journal of Pharmaceutical and Clinical Research 2018, 11, 359-363 https://doi.org/10.22159/ajpcr.2018.v11i5.24578.

19. Ahmad, W.; Kumar, P.; Chaturvedi, A.K. Study the effect of UV light on the antimicrobial activity of Euphorbia hirta leaf extract. Journal of Pharmacognosy and Phytochemistry 2019, 8.

20. Waheed, K.; Muhammad, S.K.; Shomaila, A.; Muhammad, Z.; Izhar, U.; Ullah, S. Antimicrobial Activity and Phytochemical Screening of Euphorbia helioscopia. J Planta Daninha 2020, 38, https://doi.org/10.1590/s0100-83582020380100011.

21. Vyas, M.; Desai, B. Phytochemical screening and antimicrobial activity of flower extract of Euphorbia milii. BMR Phytomedicine 2018, 4, 1-6.

22. Lin, L.J.; Marshall, G.T.; Kinghorn, A.D. The Dermatitis-Producing Constituents of Euphorbia hermentiana Latex. Journal of Natural Products 1983, 46, 723-731, https://doi.org/10.1021/np50029a020.

23. Özbigin, S.; Çitoğlu, G. Uses of some Euphorbia species in traditional medicine in Turkey and their biological activities. Turkish Journal of Pharmaceutical Sciences 2012, 9, 241-256.

24. Pereira, J.P.; de Souza, C.P.; Mendes, N.M. Molluscicidal properties of the Euphorbia cotinifolia L (author's transl). Revista brasileira de pesquisas medicas e biologicas 1978, 11, 345-351.

25. McDonald, M.; Mila, I.; Scalbert, A. Precipitation of Metal Ions by Plant Polyphenols: Optimal Conditions and Origin of Precipitation. J Agric Food Chem 1996, 44, 599-606, https://doi.org/10.1021/jf950459q.

26. Tang, Q.; Su, Z.; Han, Z.; Ma, X.; Xu, D.; Liang, Y.; Cao, H.; Wang, X.; Qu, X.; Hoffman, A.; Liu, H.; Gu, D.; Qiu, D. LC-MS method for detecting prostratin in plant extracts and identification of a high-yielding population of Euphorbia fischeriana. Phytochemistry Letters 2012, 5, 214-218, https://doi.org/10.1016/j.phytol.2011.12.011.

27. Runyoro, D.; Ngassapa, O.; Nondo, R.; Melkiory, P. Antifungal activity against onychomycosis causative fungi and brine shrimp lethality of a Tanzanian ornamental plant Euphorbia cotinifolia L. (Euphorbiaceae). 2017, 9, 63-67.

28. Salehi, B.; Iriti, M.; Vitalini, S.; Antolak, H.; Pawlikowska, E.; Kręgiel, D.; Sharifi-Rad, J.; Oyeleye, S.I.; Ademiluyi, A.O.; Czopek, K.; Staniak, M.; Custódio, L.; Coy-Barrera, E.; Segura-Carretero, A.; CádizGurrea, M.D.; Capasso, R.; Cho, W.C.; Seca, A.M.L. Euphorbia-Derived Natural Products with Potential for Use in Health Maintenance. Biomolecules 2019, 9, https://doi.org/10.3390/biom9080337. 